ks. Witold Ostafiński

\title{
„Ocknij się! Dlaczego śpisz, Panie? Przebudź się! Nie odrzucaj na zawsze!". O przemówieniu Benedykta XVI w Auschwitz
}

Podczas pierwszej pielgrzymki Benedykta XVI do Polski szczególnym zainteresowaniem mediów polskich i zagranicznych cieszyła się wizyta papieża w byłym hitlerowskim obozie zagłady Auschwitz-Birkenau. Można było przypuszczać, że wystąpienie Ojca Świętego na największym cmentarzu Europy będzie jednym z najważniejszych wydarzeń pielgrzymki i że będzie wstrząsające. Tak się też stało. Przemówienie papieża pochodzącego z Niemiec wygłoszone 28 maja 2006 roku w Oświęcimiu wywarło na słuchaczach ogromne wrażenie. Właściwie nie było to przemówienie, co raczej wielki manifest na cześć Dobra, wygłoszony wobec świata i dla świata, i - co bardzo istotne - za świat. Manifest wygłoszony na Golgocie XX wieku, na oczach mieszkańców ziemi - ludzi dobrej i złej woli. Skierowany do jednych, by trwali mocno w wierze na drogach swego życia, w służbie dobru, i do drugich, aby „Bóg pomógł im opamiętać się i zrozumieć, że przemoc nie buduje pokoju, ale rodzi tylko dalszą przemoc - potęgując zniszczenie, które sprawia, że w ostatecznym rozrachunku przegrywają wszyscy"1.

Szczególnie wstrząsające stały się słowa zaczerpnięte z Psalmu 44 stanowiące niejako tekst naczelny, czyli motto całego przemówienia. Cytowany kilkakrotnie fragment Psalmu funkcjonuje na zasadzie powracającego stale motywu, tzw. leitmotivu: „Ocknij się! Dlaczego śpisz, Panie? Przebudź się. Nie odrzucaj na zawsze! Dlaczego ukrywasz oblicze, zapominasz o nędzy i ucisku naszym?" (Ps 44, 24-25). Słowa skierowane do Boga dramatyzują tekst, spajają go wewnętrznie, porządkują i segmentują wypowiedź.

Papież rozpoczął swą homilię bardzo osobistym i emocjonalnym tonem, podkreślając swoje niemieckie pochodzenie: „Mówić w tym miejscu kaźni i niezliczonych zbrodni przeciwko Bogu i człowiekowi, niemających sobie

${ }^{1}$ Por. J. Puciłowski, Bóg uśmiechnąt się do swego stworzenia. Po wizycie Benedykta XVI w Oświęcimiu i Brzezince, http://www.liturgia.dominikanie.pl/dokument.php?id=934 (1 lutego 2008). 
równych w historii, jest rzeczą prawie niemożliwą - a szczególnie trudną i przygnębiającą dla chrześcijanina, dla papieża, który pochodzi z Niemiec"’2. Trzy razy papież nawiąże do swego rodowodu niemieckiego, dając wyraz niewypowiedzianemu ciężarowi, jaki na nim spoczywa. W swym przejmującym przesłaniu papież odniósł się do najbardziej fundamentalnych pytań, jakie może postawić człowiek wobec takiej zbrodni. „W miejscu takim jak to brakuje słów, a w przerażającej ciszy serce woła do Boga: Panie, dlaczego milczałeś? Dlaczego na to przyzwoliłeś?"’3. Te dramatyczne pytania będące trawestacją Psalmu 44 nadają emocjonalnego charakteru papieskiej wypowiedzi. Mówca kieruje swoje pytania bezpośrednio do Boga, tak jak to czynią Żydzi, ale odpowiedzi na nie daje już w perspektywie chrześcijańskiej, respektując to wszystko, co jest milczeniem i tajemnicą. Benedykt odniósł się do podstawowego problemu teologicznego: nieobecności Boga w Auschwitz, przypominając jednocześnie, że chrześcijanin nie jest zwolniony z obowiązku zmierzenia się z pytaniem, gdzie był Bóg, gdy rozgrywało się oświęcimskie misterium iniquitatis ${ }^{4}$. Papież podkreślił, że stosowną odpowiedzią wobec grozy obozu zagłady jest cisza. To prawda, brakuje słów, gdy rozpamiętuje się ogrom mordu i terroru, który tam miał miejsce ${ }^{5}$.

Benedykt XVI nawiązuje w swoim wystąpieniu do wizyty w Auschwitz 27 lat wcześniej swojego wielkiego poprzednika Jana Pawła II, cytuje fragment jego homilii i powtarza za nim dwukrotnie wymowne słowa: „Nie mogłem tu nie przybyć. Przybyć tu musiałem”. I następnie dodaje: „Był to i jest obowiązek wobec prawdy, wobec tych, którzy tu cierpieli, obowiązek wobec Boga - jestem tu jako następca Jana Pawła II i jako syn tego narodu, nad którym grupa zbrodniarzy zdobyła władzę przez zwodnicze obietnice wielkości i przywrócenia honoru i znaczenia narodowi, roztaczając perspektywy dobrobytu, ale też stosując terror i zastraszenie, by posłużyć się narodem jako narzędziem swojej żądzy zniszczenia i panowania. Tak, nie mogłem tu nie przybyć". Podobnie jak w innych miejscach, tak i tu, w Birkenau, Benedykt XVI podkreśla, że podąża śladami poprzednika. Podczas pierwszej pielgrzymki do ojczyzny w 1979 roku Jan Paweł II apelował w Birkenau o poszanowanie praw człowieka. Ponad ćwierć wieku

${ }^{2}$ Przemówienie papieża Benedykta XVIw Auschwitz-Birkenau 28 maja 2006 roku, [w:] Bóg i Auschwitz. O Edycie Stein, wizycie Benedykta XVI i Bogu w mrokach dziejów, pod red. M. Deselaersa, L. Łysienia i J. Nowaka, Kraków 2007, s. 105.

${ }^{3}$ Tamże.

${ }^{4}$ Por. M. Zając, Nic prócz popiołu, ,Tygodnik Powszechny” 42 (2006).

${ }^{5}$ Por. M. A. Singer, Każdy będzie siadywat pod swa winorośla, , ,Tygodnik Powszechny” 27 (2006).

${ }^{6}$ Przemówienie papieża Benedykta XVI w Auschwitz-Birkenau 28 maja 2006 roku, dz. cyt., s. 105-106. 
później jego następca wykorzystał wizytę na gruzach krematoriów, by wysłać w świat równie ważny sygnał: te gruzowiska dają świadectwo, że dobro zwycięża, a u końca ciemnej doliny płonie światło ${ }^{7}$.

Papież dobitnie określa cel swojej wizyty w tym miejscu kaźni: ,jestem tu dziś: aby prosić o łaskę pojednania - aby prosić przede wszystkim Boga, bo tylko On może otworzyć i oczyścić ludzkie serca; ale również ludzi, którzy tu cierpieli. Modlę się o dar pojednania wszystkich, którzy w tej godzinie naszych dziejów wciąż cierpią pod panowaniem nienawiści i przemocy zrodzonej przez nienawiść" sze papieskie przesłanie. Można podziwiać odwagę Benedykta XVI, że w swym przemówieniu nie użył słowa „przebaczenie”, jakie często pada w kontekście wojny, holocaustu, ale mówił właśnie o pojednaniu. On tu nie przyjechał prosić o przebaczenie. Wiedział bowiem, że to nie sprawa instytucji, lecz sprawa między ludźmi - tymi, którzy zostali skrzywdzeni, i tymi, którzy krzywdzili. Pojednanie zaś jest poszukiwaniem ładu, wewnętrznego porządku duchowego, na czele którego stoi Bóg. Przesłanie to obejmuje nie tylko tych, którzy wciąż jeszcze cierpią z powodu tragedii sprzed ponad 60 lat, ale każdego, kto wplątany jest w nienawiść do drugiego człowieka.

Papież wykorzystuje semantykę miejsca i historię. Mówi o obozie zagłady jako o miejscu „kaźni i niezliczonych zbrodni przeciwko Bogu i człowiekowi, niemających sobie równych w historii" ${ }^{\circ}$. Kilkakrotnie używa określeń funkcjonujących na zasadzie amplifikacji: „,ciemność”, „ciemna dolina”, „ciemność nocy”, „mroki terroru”, „moce ciemności”. Nie czyni tego po to, by poinformować słuchaczy o pewnych faktach, bo są one doskonale im znane. Nie informacje są tu najistotniejsze, ale budowanie wspólnoty przez przywołanie tragicznej przeszłości, oparte na przekonaniu, że teraźniejszość ma swoje korzenie w przeszłości i bez niej niemożliwe jest pojednanie. Posługując się słowami Psalmu, wygłosił najwspanialszy hymn na cześć pomordowanych: „Przez wzgląd na Ciebie ciągle nas mordują, mają nas za owce na rzeź przeznaczone”. Te słowa „w okrutny sposób się spełniają. W istocie, bezwzględni zbrodniarze, unicestwiając ten naród, zamierzali zabić Boga, który powołał Abrahama, a przemawiając na Górze Synaj, ustanowił zasadnicze kryteria postępowania ludzkości, obowiązujące na wieki"10.

${ }^{7}$ M. Olszewski, Światto z ciemnej doliny, „Tygodnik Powszechny” 23 (2006).

${ }^{8}$ Przemówienie papieża Benedykta XVI w Auschwitz-Birkenau 28 maja 2006 roku, dz. cyt., s. 106.

${ }^{9}$ Przemówienie papieża Benedykta XVI w Auschwitz-Birkenau 28 maja 2006 roku, dz. cyt., s. 105.

${ }^{10}$ Przemówienie papieża Benedykta XVI w Auschwitz-Birkenau 28 maja 2006 roku, dz. cyt., s. 107. 
Jest to fragment uderzający, który dotyczy najtrudniejszych spraw ludzkości i w nowy sposób ukazuje problem ludobójstwa. Benedykt XVI wygłosił ważną pointę tamtych tragicznych wydarzeń, która dziś ma szczególny wymiar: że naziści „Wyniszczając Izrael, dokonując Szoah, chcieli w rzeczywistości wyrwać korzenie wiary chrześcijańskiej i zastąpić ją przez siebie stworzoną wiarą w panowanie człowieka - człowieka mocnego"11. Papież połączył w jedną retoryczną figurę nienawiść do narodu wybranego i nienawiść do Boga. Użył figury bardzo dobrze znanej w teologii żydowskiej, pojawiającej się w nauczaniu rabinów, a dotyczącej holocaustu. Sprowadza się ona do uznania, że śmierć wierzących to zastępcza forma śmierci Boga i że holocaust był zabijaniem samego Boga. Szukając przyczyn szoah, Benedykt XVI jako główny motyw wskazał obecne w kulturze europejskiej dążenie do eliminacji Boga, za co szczególną cenę musiał zapłacić naród wybrany. Papież podkreśla, że Auschwitz stanowiło próbę zniszczenia żydowskiego narodu i jego tradycji, która stanowi źródło dwóch innych religii monoteistycznych: chrześcijaństwa i islamu. Bez wątpienia fragment ten stanowi specyficzne martyrium, które nie polega na wyłożeniu systemu wartości poprzez egzemplifikację pozytywną. Pokazanie przykładu negatywnego, którego wymowa jest dla słuchaczy oczywista, jeszcze silniej wpływa na emocje i wolę słuchaczy ${ }^{12}$. Przykład taki jest świadectwem tego, co zagraża ludzkości wówczas, gdy człowiek, zapominając o Bożych prawach, staje przeciwko drugiemu człowiekowi. Nietrudno zauważyć, że ośrodkiem tego fragmentu czyni mówca słowa: mrok, ciemność.

Całe przemówienie papieża jest wymierzone w zbrodnię i moce ciemności, które zdają się na nowo odradzać w ludzkich sercach: „Zanośmy to wołanie do Boga, skierujmy je również do naszych serc właśnie teraz, gdy pojawiają się nowe zagrożenia, gdy w ludzkich sercach zdają się panować na nowo moce ciemności: $\mathrm{z}$ jednej strony nadużywanie imienia Bożego dla usprawiedliwienia ślepej przemocy wobec niewinnych osób; z drugiej cynizm, który nie uznaje Boga i szydzi z wiary w Niego"13. Papież dokonuje aktualizacji w wymiarze ogólnoludzkim, w wymiarze cierpień, krzywd i przemocy, które dzieją się w różnych częściach świata. Odnosi się do tych wszystkich miejsc, w których „,poniżana i gwałcona jest godność człowieka, i gdzie w sposób cyniczny odrzuca się Boga, próbując budować życie bez

${ }^{11}$ Tamże.

${ }^{12}$ Por. Retoryka na ambonie, pod red. P. Urbańskiego, Kraków 2003, s. 114.

${ }^{13}$ Przemówienie papieża Benedykta XVI w Auschwitz-Birkenau 28 maja 2006 roku, dz. cyt., s. 106-107. 
Niego"14. Papież sięgnął do najgłębszych korzeni dobra i zła, z którego rodzi się konkretna forma nienawiści ${ }^{15}$.

Tragiczne doświadczenie pierwszej połowy XX wieku co prawda minęło, ale znów zdaje się odradzać. Człowiek współczesny nie wyzbył się żądzy władzy i nienawiści, a więc - jak widać - nie wyciągnął żadnych wniosków z minionych wydarzeń. Dlatego fragment ten, choć nie bezpośrednio, staje się nawoływaniem do opamiętania i ostrzeżeniem przed grzechem nienawiści.

Przemówienie Benedykta XVI wygłoszone w cieniu krematoriów i komór gazowych jest przejmującym ostrzeżeniem przed wciąż obecnymi w naszej cywilizacji elementami, które w przyszłości mogą przynieść równie tragiczne skutki. Tragedia, jaka rozegrała się w Auschwitz-Birkeanu, nie jest tylko zamkniętą kartą historii, lecz wciąż aktualnym wyzwaniem do pogłębionej refleksji nad kondycją człowieka, kulturą, jaką tworzy, i modelem świata, jaki zamierza budować ${ }^{16}$.

Niezwykła jest też refleksja Benedykta XVI dotycząca tablic upamiętniających ofiary obozu różnych narodowości, „losy nieprzeliczonych rzesz ludzi”"17, „Świadków prawdy i dobra”18, których nazywa światłem w ciemnościach nocy ${ }^{19}$. Bardzo osobisty charakter ma wspomnienie św. Teresy Benedykty od Krzyża, która zginęła „w ciemnościach osnuwających obóz koncentracyjny”20: „Odczuwałem wewnętrzną potrzebę, by zatrzymać się zwłaszcza przed tablicą z napisem w języku niemieckim. Tu staje nam przed oczami oblicze Edyty Stein"21. W tym miejscu, na zasadzie analogii, przywołuje biblijnych młodzieńców z Księgi Daniela - odważnych świadków wiary, którzy nie chcieli oddać pokłonu posągowi wzniesionemu przez okrutnego króla Nabuchodonozora i woleli ponieść męczeńską śmierć w rozpalonym piecu.

Zwróćmy w tym miejscu uwagę, że cały tekst okazuje się wynikiem spotkania tekstów biblijnych z określonym momentem historycznym, przeszłością narodu wybranego. Argumentacja, jaką posługuje się papież, odwołuje się do czterech źródeł: Biblii, historii, literatury oraz współczes-

${ }^{14}$ Por. Rozmowa Jarosława Borowca z abp. Henrykiem Muszyńskim. Hebrajski Papież, „Tygodnik Powszechny” 24 (2006), s. 10.

15 Tamże.

${ }^{16}$ Wobec tajemnicy Auschwitz, http://www.ksm.lublin.pl/modules/mysections/article. php?lid=50 (1 lutego 2008).

${ }^{17}$ Przemówienie papieża Benedykta XVI w Auschwitz-Birkenau 28 maja 2006 roku, dz. cyt., s. 108.

\footnotetext{
${ }^{18}$ Tamże.

${ }^{19}$ Por. tamże.

${ }^{20}$ Tamże.

${ }^{21}$ Tamże.
} 
ności. Bardzo interesująca jest analogia tych obszarów. Mówca sięga do biblijnych psalmów. Cytowane już wstrząsające słowa Psalmu 44 nazywa krzykiem zniewolonego Izraela: Papież powiedział, że ten „krzyk trwogi cierpiącego Izraela, który wzywa Boga w godzinie ogromnej udręki, jest równocześnie wołaniem o pomoc wszystkich ludzi, którzy w historii - wczoraj, dziś i jutro - płacą cierpieniem za umiłowanie Boga, prawdy i dobra; a jest ich wielu, również dziś2 22 ". W tym miejscu nie można nie być porażonym myślą, gdzie w tamtych chwilach było skierowane oblicze Boga Abrahama, Izaaka i Jakuba, który, zdawać by się mogło, nie widział niewyobrażalnej rzezi swojego narodu. Tu znów padają dramatyczne pytania: Gdzie był Bóg w tamtych czasach? Dlaczego milczał? Jak mógł pozwolić na taki triumf zła? Właśnie ten krzyk przejął słuchaczy najbardziej i pozostał w ich pamięci do dziś. Ten krzyk, bliski nie tylko żydowskiej teologii, ale także każdemu, kto wadzi się z Bogiem, czyli próbuje pogodzić wiarę w Jego dobroć i wszechmoc z przemożnym panowaniem Złego. Papież polemizuje $z$ ateizmem rozpaczy, komentując dalej, że Bóg jest tajemnicą. Skoro widzimy tylko jej fragment, nie powinniśmy być sędziami Boga i historii, bo zniszczymy w ten sposób człowieka. Niemniej do Boga mamy wytrwale, pokornie i natarczywie wołać: „Przebudź się!”23.

Papież czerpie inspirację także z literatury. Snując refleksję nad martyrologia poszczególnych narodów uwiecznioną w rzędzie kamiennych tablic, przywołuje słowa bohaterki z antycznej tragedii Sofoklesa - Antygony: "Nie jestem tu, aby razem nienawidzić, lecz by razem miłować"24. Mocno brzmią te słowa w miejscu, gdzie człowiek zanegował postawę dialogu, jakiego nauczył nas Bóg - zanegował miłość.

Auschwitz jest wiecznie wstrzymywanym oddechem w oczekiwaniu na słowo Pana, tak jak w poruszającym opisie ciszy poprzedzającej objawienie na Synaju, który daje nam Talmud: „Cisza była taka, że zwierzęta przestały ryczeć, psy - szczekać, wiatr - wiać, morze - poruszać się, ptaki - śpiewać... Cały wszechświat wstrzymał oddech w oczekiwaniu boskiego słowa"25.

W obozie Auschwitz-Birkenau ludzkość przeszła przez „ciemną dolinę”. Papież w zakończeniu swojej homilii zacytował dłuższy fragment Psalmu 23 będącego modlitwą Izraela i modlitwą chrześcijan: „Pan jest moim pasterzem, nie brak mi niczego. Pozwala mi leżeć na zielonych pastwiskach. Prowadzi mnie nad wody, gdzie mogę odpocząć: orzeźwia moją duszę.

${ }^{22}$ Tamże, s. 106.

${ }^{23}$ Por. Boże, nie milcz. Komentarz Jana Turnaua. Zob. wiadomosci.gazeta.pl/benedyktxvi.

${ }^{24}$ Przemówienie papieża Benedykta XVI w Auschwitz-Birkenau 28 maja 2006 roku, dz. cyt., s. 108.

${ }^{25}$ Por. M. Zając, Nic prócz popiołu, art. cyt. 
Wiedzie mnie po właściwych ścieżkach przez wzgląd na swoje imię. Chociażbym przechodził przez ciemną dolinę, zła się nie ulęknę, bo Ty Jesteś ze mną. Twój kij i Twoja laska są tym, co mnie pociesza... Zamieszkam w domu Pańskim po najdłuższe czasy" (Ps 23, 1-4, 6).

Zestawieniem, porównaniem na zasadzie kontrastu słów z Psalmu 23: „ciemna dolina”, a zaraz potem: „zła się nie ulęknę, bo ty jesteś ze mną” papież pokazuje triumf dobra i miłości. Swoją wizytę na gruzach krematoriów wykorzystuje, by dać światu świadectwo, że w ostateczności dobro zwycięża, a u końca ciemnej doliny płonie światło ${ }^{26}$.

Przemówienie Benedykta XVI przepojone kategoriami biblijnymi wydaje się najpiękniejszym komentarzem do Księgi Psalmów - księgi modlitwy ludu Bożego i wspaniałym wykładem wiary: nadzwyczaj prostym, a jednocześnie niezwykle głębokim. Papież wskazał miejsce Polski w Europie nie tylko jako miejsce świadectwa wiary, ale także budowania pojednania. To jest najgłębsza myśl, która wynika z pobytu w Auschwitz-Birkenau.

Obecność papieża niemieckiej narodowości w byłym obozie koncentracyjnym miała symboliczną i historyczną wymowę, była szczególnym znakiem na drodze pojednania i dialogu między Żydami, Niemcami i Polakami. Papież wystąpił w wielu rolach - w roli najwyższego kapłana, teologa, polityka, a także Niemca, „syna narodu niemieckiego”. Od polityka usłyszeliśmy słowa zobiektywizowane, o historycznej wiarygodności, słowa aktualne, a zarazem zwrócone w przyszłość. Od kapłana - słowa ponadczasowe, niosące przesłanie nadziei dla żywych, wierzących i niewierzących, i przekaz miłości dla umarłych. Usłyszeliśmy słowa współczucia i solidarności z ofiarami zbrodni nazistowskich. Papież pokazał, że to straszliwe miejsce może być znakiem nadziei i pojednania. Każdy, kto słuchał jego słów, odkrył w nich prawdę o nas samych i wyzwaniach, jakie stawia przed nami Ewangelia.

Przemyśl

KS. WITOLD OSTAFIŃSKI

\section{Słowa kluczowe}

Auschwitz, Benedykt XVI, Żydzi, Polacy, Niemcy, naziści, Golgota XX wieku, ludobójstwo, holokaust, przemoc, terror, cierpienie, nienawiść, obóz koncentracyjny, odrzucenie Boga, pojednanie, dialog

${ }^{26}$ Por. M. Olszewski, Światło z ciemnej doliny, art. cyt. 


\title{
Summary
}

\begin{abstract}
"Wake up! Why are you asleep, Lord? Wake up! Do not reject forever!". About Benedict XVI's speech in Auschwitz

The contents of the article contain an analysis of Benedict XVI's speech delivered in Auschwitz-Birkenau during his first pilgrimage to Poland in 2006. The author subjects the papal speech to rhetorical analysis, which aims to display reciprocal relations between three most important domains of rhetoric: invention, disposition, and elocution. The author pays particular attention to the arguments that the Pope utilises referring to three sources: the Bible, history, literature and the present. The analogy of these areas, thanks to rhetorical amplification, serves to extract and reveal the depth of historical ideas. The papal speech, filled with biblical references, is a clear lecture of faith and a moving manifesto in honour of good and the need for interpersonal love. According to Benedict XVI, Auschwitz-Birkenau, that he called the largest European cemetery, should become a symbol of hope and reconciliation of the nations of modern Europe.
\end{abstract}

\section{Keywords}

Auschwitz, Pope Benedict XVI, Jews, Poles, Germans, Nazis, $20^{\text {th }}$ century Golgotha, extermination camp, genocide, holocaust, violence, terror, suffer, hatred, reject God, reconciliation, dialogue 